\title{
Accurate Training Assistance for Accounting Vocational High School Teachers to Improve the Capability of Computer Accounting Program
}

\author{
Titis Puspitaningrum D.K, Riski Aprilianita \\ STIE Perbanas Surabaya \\ Titis_puspita@perbanas.ac.id
}

\begin{abstract}
Partner problems faced in Accounting Vocational High School Teachers in Surabaya also become a problem for other schools. Learning about accurate is still being a discourse so far and it requires teachers to improve their abilities and knowledge. This makes all high school especially Accounting Vocational High school teachers need to be trained about accurate learning. The purpose of this training is to develop their knowledge related to computers and fulfill the needs of companies who need to use the accurate program. As a result, this program will bring benefit for graduated students so they will easily find a job in the future. To solve this problems, the writer did the assistance on the Subject Teacher Organization (MGMP) Accounting group in Surabaya by providing accurate training. The average results of pre and posttest increases 18.25 points. The result obtained from pre and posttest is very satisfying which $87.5 \%$ of teachers received higher point after doing the training. Only one teacher whose point did not change and two teachers whose point decreased and only one teacher whose point decreased into 3
\end{abstract}

Keywords: ability improvement, Accurate Training, Vocational High School Teachers

\begin{tabular}{ccc}
\hline Received & Revised & Published \\
April $11^{\text {th }} 2019$ & ${\text { June } 14^{\text {th }} 2019}^{\text {th }} 2019$ \\
\hline
\end{tabular}

\section{INTRODUCTION}

Indonesia's Open Unemployment Rate (TPT) in February 2017 has decreased to $5.33 \%$ from last year. There are 131.55 million people who enter as the labor force, 124.54 million people who work and the rest 7.01 million people are confirmed unemployed. The number of unemployed people who came from the Vocational High School (SMK) ranks at the top of $9.27 \%$. The contribution of SMK graduates to the number of unemployed people in Indonesia is partly due to the low specialized skills or soft skills of SMK graduates (except those whose competencies have been tested), quoted in http://detikfinance.com. This is reinforced by the findings of Djashan (2017) which states that changes in scope of work demand is faster than changes in school curricula. The ability to recognize accounting software earlier will help students adapt more easily to the working environment.

The development of Information Technology (IT) which is increasingly rapid in the current era of globalization has an impact on the world of education, especially the existence of the industrial revolution 4.0. This requires the teacher to adjust the development of IT to improve the quality of learning. These qualities can be improved by innovating the development of attractive and communicative teaching materials. This indicates that the teacher needs to do the right strategies in delivering material at school.

The development of the industrial revolution has actually been applied to schools, especially vocational high schools by providing subjects using computer application programs. For 
example, at Al' Fatah Kalitidu Bojonegoro Vocational High School, the teachers have taught the accounting computer program MYOB V 18 TRIAL program. Along with the addition of a new accounting program, the teachers also need to learn and practice so that when there is a change in the computer accounting program, the teachers are not preoccupied with seeking for more training. The problems experienced by accounting teachers give us a discourse to provide assistance in the form of accounting faced training for teachers, one of which is accurate training.

ACCURATE Accounting Software was created by Putra / Putri Bangsa Indonesia, which is under the auspices of PT. Cipta Piranti Sejahtera, known as CPSSoft, located in Jakarta. ACCURATE Accounting Software is the first software developed by CPSSoft. In developing software, CPSSoft always uses the basic principles of 3M, namely Murah (Cheap), Massal (Mass), and Manfaat (Advantageous).

Accurate accounting is a software that is used to simplify the management of financial data with a high degree of accuracy so that it produces financial reports and balance sheets more quickly. The advantages of this accurate program besides being very easy to use, it has been equipped with tax features that are suitable with Indonesian taxation. Most programs still do not have this feature but accurate accounting has. In addition to have used the accounting standards applied in Indonesia, this accurate accounting program is able to calculate transaction values up to 15 digits, meaning transaction that can be calculated is around 920 trillion.

After analyzing the situation, most companies have started to use this computer accounting programs besides MYOB. It makes the graduated students of high school / vocational high school become less valuable, so the chairwoman of MGMP East Java delivered a discourse about the change in material that will be taught to students. One of the discourses is the change of learning material for accounting practices from the MYOB program to the accurate program. The discourse makes teachers need training that is not learned just once because accurate $\mathrm{pr}$

\section{LITERATURE REVIE}

Improving the good quality of human resources is a challenge faced by teachers, because the success of an education is determined by the way the professionalism of educators teach.

According to Bloom's Taxonomy, knowledge is defined as cognitive aspects which include:

1. Knowing: recognizing general and specific things, re-recognizing methods and processes, re-recognizing structures and devices, and understanding, can be defined as comprehending

2. Applying: the ability to use abstract in concrete situations

3. Analyzing: describe something into the elements of parts or simple components or hierarchies expressed in a communication

4. Synthesizing: is the ability to unite the elements or parts in such a way as to form a communication

5. Evaluating: the ability to determine the value or price of communication methods for certain purposes.

The components of the learning strategy include:

1. Material selection, includes instructional objective criteria, relevant to needs, material arranged in scope and systematic sequence, 
2. Method of delivering material, including demonstration, command style, training style, reciprocal style, game tactics approach

3. Communication in learning strategies include oral, auditory, visual, classroom management

"Accurate" Accounting Program - There are many accounting software that offers various applications depending on the needs of users. Common problems that occur are:

1. Difficult to track items going in and out and difficult to monitor stock

2. Difficult to monitor vendor/customer's debt, difficult to monitor the age of debt

3. Expect to monitor earnings quickly and require to have ready-made financial reports

4. Miscalculated of debt payment and non-deposited payments from customers

There are many problems faced by financial report users and they can be solved when our choice in selecting the tools (in this case is accounting computer applications) are suitable with what is needed by users. All modern businesses have accounting software as a tool to facilitate and speed up administrative tasks that require accuracy and high security. Accurate accounting software is one software that offers several advantages that make it easier for users in making financial reports. One of them is that this software helps to complete financial reports even though the users do not really understand the basics of accounting. Transactions in this software include sales, purchases, inventory, service sales, make a cost notes up to the preparation of financial reports in a few steps precisely and accurately.

\section{METHODS}

This community service program used teaching methods, discussion training, and feedback to the teachers. The assistance was focused on the training by using computer program. The method of this community service program could be presented in the figure as followed:

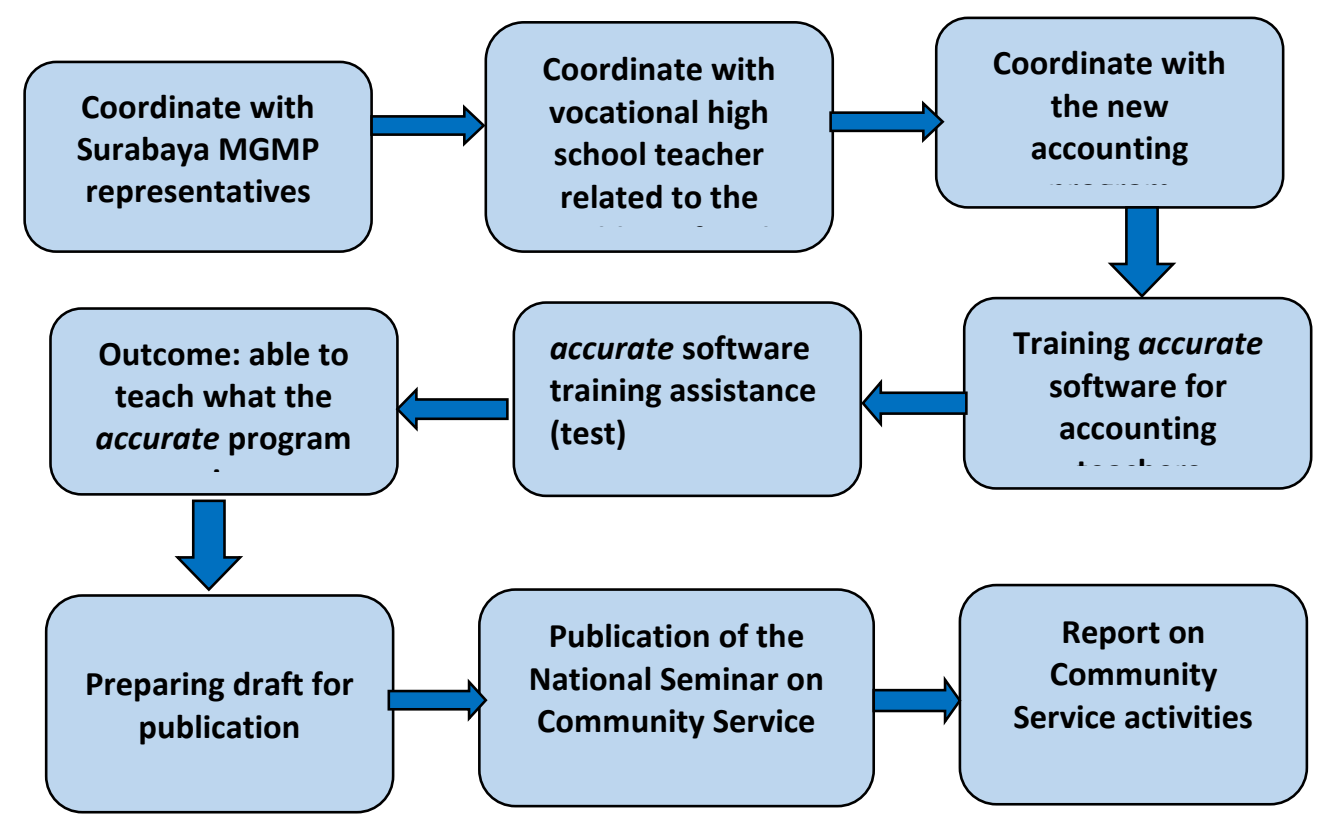

Figure 1.1 Activity implementation framework

The method of implementing community service activities began by coordinating with Mrs. Setyo Budi as a deputy chairwoman of the Accounting Subject Teacher Organization 
(MGMP) who is also a teacher staff at SMKN 1 Surabaya. In this coordination, it was conveyed that knowledge of computer accounting was still limited to the subjects presented. The subject matter was presented in the form of accounting practices using MYOB. Based on the phenomenon, the head of Subject Teacher Organization (MGMP) East Java began to inform accounting teachers to learn using the accurate computer program because the MYOB program would be replaced with the accurate program. The coordination was very much accepted by the deputy chairwoman of MGMP Surabaya so that the implementation of this activity would fully coordinate with Mrs. Setyo Budi. The results of the coordination found that the training plan was started for the teachers of State Vocational High Schools in advance where on average their schools had an accurate program. In addition, State Vocational Schools would more quickly implement accurate programs on their students even though this program was still not being a compulsory subject. This activity was planned for 20 Vocational High School teachers in Surabaya who would be informed via the Surabaya Accounting MGMP group.

This community service was held in stages for two to four days where the activity starts with an explanation of theory, practice and test. It was intended that vocational high school teachers are able to understand and practice the program accurately. This activity was carried out from the last June at STIE Perbanas Surabaya.

The main stage of the activity was determining the participant who would be involved in this activity, namely:

1. Schools / education offices that identified the needs of the organization in preparing future challenges

2. Principals who were the ones who are most responsible for the success of a job and who know best what type of training needs are needed

3. The teachers who were given the opportunity to take part in a particular training program, where the teacher is certainly intellectually mature and explores his potential to need a learning effort.

The training activity is a budget that is provided by the school itself. So that every training must be carefully analyzed needs that provide benefits for teachers and schools. So, those who attend the training must be competent and have benefits for the teachers, the school and for students. Training in this service activity was expected to be practiced for students through training for students.

Based on the needs analysis, then set various targets to be achieved from a training activity, both technical and behavioral in nature. For organizers, the determination of these objectives has important meanings as: (1) later benchmarks to determine the success or failure of the training program; (2) materials in an effort to determine the next steps, such as determining the contents of the program and the appropriate training methods. As for the participants, the goal setting is useful in preparation and effort what they should do in order to get the maximum benefit from the training activities that they participate in.

This activity will produce output in the form of accurate easy learning modules and publication of national seminars that will be carried out by the Indonesian Management Forum in 2019. The overall planned activities above can run smoothly with the support and participation of the training participants. Active participation provided includes:

1. Willingness to discuss issues related to the needs of teachers and students both high school and vocational high school.

2. Willingness to attend training until they are proficient in using accurate programs 


\section{RESULTS AND DISCUSSION}

These training activity partners are teachers who are members of the MGMP Group in the Surabaya and surrounding areas. After coordinating with Mrs. Setyo as MGMP Accounting deputy chairwoman, the activity is followed by choosing the school representative to participate in this activity. Of course the basis for the election is to prioritize state schools because their infrastructure is already supporting by having a computer laboratory. This does not discourage private schools because we also choose a private school that is competent with computer programs. In addition to the priority of the state, the accurate program which is still a discourse replaces the MYOB program, will later be applied to public schools for the first time. That is why we prioritize state schools to take part in this training. The names of schools participating in this activity are from:

1. SMKN 1 Surabaya 4 teachers

2. SMKN 10 Surabaya 2 teachers

3. SMKN 10 Surabaya 2 teachers

4. SMKN 6 Surabaya 2 teachers

5. SMKN 1 Bangkalan 2 teachers

6. SMKN III Bangkalan 1 teachers

7. SMKN 1 Sampang 1 teachers

8. $\quad$ SMK Al Fatah Bojonegoro 3 teachers

From 8 schools, 17 teachers were obtained from Surabaya, Madura and Bojonegoro.

Training activities for teachers are basically an integral part of management in the field of personnel in schools and are efforts to develop teacher knowledge and skills so that in turn teachers are expected to gain competitive advantage and can provide the best possible service or in other words they can work more productively and be able to improve the quality of performance.

The implementation of accurate training activities is carried out for 4 meetings with details of 2 times face to face and 2 independent assignments. This activity was attended by 18 teachers from Surabaya and surrounding and $80 \%$ of whom came from State Vocational Hig Schools.

Pre-test and post-test are used to see the extent of improving the ability of teachers in this training activity.

Table 1.1 The result of Pre Test and Post Test of Accurate Training

\begin{tabular}{|l|l|l|l|l|}
\hline No & Name & Pre-Test & Post-Test & Result \\
\hline 1 & Setyo Budiwati & 50 & 77 & $\begin{array}{l}\text { Improve 27 } \\
\text { points }\end{array}$ \\
\hline 2 & Anik Gunawanti & 50 & 74 & $\begin{array}{l}\text { Improve 24 } \\
\text { points }\end{array}$ \\
\hline 3 & Nurod Osianto & 57 & 70 & $\begin{array}{l}\text { Improve 13 } \\
\text { points }\end{array}$ \\
\hline 4 & Hadi Sasongko & 64 & 90 & $\begin{array}{l}\text { Improve 26 } \\
\text { points }\end{array}$ \\
\hline 5 & Sumiatun & 54 & 54 & $\begin{array}{l}\text { No } \\
\text { improvement }\end{array}$ \\
\hline 6 & Prestiwati & 44 & 64 & $\begin{array}{l}\text { Improve 24 } \\
\text { points }\end{array}$ \\
\hline
\end{tabular}




\begin{tabular}{|c|c|c|c|c|}
\hline 7 & Endah Woelandari & 50 & 60 & $\begin{array}{l}\text { Improve } 10 \\
\text { points }\end{array}$ \\
\hline 8 & Hariyanto & 50 & 47 & $\begin{array}{l}\text { decrease } 3 \\
\text { points }\end{array}$ \\
\hline 9 & Khoirul Mutholibin & 50 & 67 & $\begin{array}{l}\text { Improve } 16 \\
\text { points }\end{array}$ \\
\hline 10 & Arin Yuni & 74 & 84 & $\begin{array}{l}\text { Improve } 10 \\
\text { points }\end{array}$ \\
\hline 11 & Titik Budiarsih & 24 & 44 & $\begin{array}{l}\text { Improve } 20 \\
\text { points }\end{array}$ \\
\hline 12 & Ema Sulifiana & 60 & 97 & $\begin{array}{l}\text { Improve } 37 \\
\text { points }\end{array}$ \\
\hline 13 & Muharromah & 50 & 70 & $\begin{array}{l}\text { Improve } 20 \\
\text { points }\end{array}$ \\
\hline 14 & Listut handayani & 44 & 60 & $\begin{array}{l}\text { Improve } 24 \\
\text { points }\end{array}$ \\
\hline 15 & Linda Handayani & 54 & 74 & $\begin{array}{l}\text { Improve } 20 \\
\text { points }\end{array}$ \\
\hline 16 & Gusti Ratmawati & 50 & 74 & $\begin{array}{l}\text { Improve } 24 \\
\text { points }\end{array}$ \\
\hline
\end{tabular}

The average results of the increase in the pre and posttest values of 18.25 points. The results obtained from the pre and posttest are very satisfying where $87.5 \%$ of teachers received higher grades after the training was held, and only one teacher whose value did not change and two teachers whose grades dropped and one teacher whose grades decreased by 3 points only.

The outputs of the implementation of the activities obtained by the participants after participating in this activity are:

1. Teachers as educators become more confident using their abilities and are able to explore the potential that exists to improve the quality of education, especially in the field of computers.

2. Educators are able to develop creativity and are able to integrate it with current technological developments which is in the field of accounting computers.

3. This activity is able to provide benefits and create a cooperation that can be beneficial for both parties (teachers and students) with attractive learning methods.

4. Form of an inspirational teacher learning forum that will facilitate further activities to increase the competence and creativity of teachers at the Surabaya city level.

The learning methodologies provided are as followed :

1. Lecture method

2. Question and answer method

3. Discussion method

4. Methods of assigning tasks

5. Discovery-inquiry method

6. Panel method

The methods are summarized in 4 days of the implementation from this activity. The importance of teaching methodology is mastered by educators, which of course must be adapted to the type of learning. In this learning activity, the participants are teachers who 
have gotten accurate material both from training / seminars or who have been taught in class.

\section{CONCLUSION}

The benefit of this community service program is to provide teachers with provisions to teach students so that they are more updated with the computer accounting program used by the company, so it will make graduated students easier to get jobs in the industrial revolution era. The method of implementing community service activities began by coordinating with Mrs. Setyo Budi as a deputy chairwoman of the Accounting Subject Teachers' Organization (MGMP Akuntansi) who is also a teaching staff at SMK 1 Surabaya. These training activity partners are teachers who are members of MGMP Group in the Surabaya and surrounded areas. The implementation of accurate training activities is carried out for 4 meetings with details of 2 times face to face and 2 independent assignments. This activity was attended by 18 participants from Surabaya's teachers and 80\% came from State Vocational High Schools. This training was held at STIE Perbanas Surabaya July 13-14 2019 in the laboratory room. The results of the implementation of this community service program are first, teachers can improve their knowledge and skills in computer accounting. Second, the ability of teachers' knowledge and skills in accurate programs increases with the proven results of pre and posttests. Finally, the teacher can teach vocational high school students majoring in accounting for a new accounting program (accurate) so that the graduates produced have competency / expertise in accounting computers that are widely used by companies.

\section{REFERENCES}

A 'la, H., Setiawan, B., \& Djarwanti, N. (2017). Penambahan Limbah Plastik Pada Tanah Ekspansif, (36), 1170-1178.

Abdurrozak, M. R., Mufti, D. N., Studi, P., Sipil, T., Islam, U., Studi, P., ... Islam, U. (2017). STABILISASI TANAH LEMPUNG DENGAN BAHAN TAMBAH ABU SEKAM, XXII(2), 416-424.

Beton Mengunakan, J., Lumajang, P., Penambahan, D., Ridwan, A., \& Chandra, A. (2018). Additive Masterpozzolith @ 402R, 3(2), 192-197.

Candra, A. I. (2018). STUDI KASUS STABILITAS STRUKTUR TANAH LEMPUNG PADA JALAN TOTOK KEROT KEDIRI MENGGUNAKAN LIMBAH KERTAS. UKaRsT, 2(2), 11. https://doi.org/10.30737/ukarst.v2i2.255

Das Braja M. (1988). Mekanika Tanah (Prinsip-Prinsip Rekayasa Geoteknis) Jilid 1 (Vol. 1). Erlangga. Retrieved from https://kupdf.net/download/mekanika-tanah-jilid-2-braja-mdas_59b0f4cfdc0d607660568edb_pdf

FAEZEHOSSADAT, K., \& JEFF, B. (2016). Expansive Soil: Causes and Treatments. I-Manager's Journal on Civil Engineering, 6(3), 1. https://doi.org/10.26634/jce.6.3.8083

Kuat, T., Dan, G., \& Tanah, K. (2018). PENGARUH STABILISASI TANAH MENGGUNAKAN KAPUR DAN MATOS TERHADAP KUAT GESER DAN KONSOLIDASI TANAH GAMBUT Aris Prabowo 1, Miftahul Fauziah, S.T., M.T., Ph.D. 1.

Ogbeche, S. (2018). Overview of Engineering Problems of Soil Compaction and Their Effects on 
Growth and Yields of Crops Overview of Engineering Problems of Soil Compaction and Their Effects on Growth and Yields of Crops. European Journal of Advances in Enineering and Technology, 5(9), 701-709.

Siswanto, E. (2019). Penambahan Fly Ash Dan Serat Serabut Kelapa Sebagai Bahan Pembuatan Beton. UKaRsT, 3(1), 48. https://doi.org/10.30737/ukarst.v3i1.352

Study, P., Sipil, T., Teknik, F., \& Kadiri, U. (n.d.). Stabilisasi struktur tanah lempung dengan menggunakan bahan tambahan abu sekam padi dan kapur pada subgrade perkerasan jalan sudjati, 1-9.

Susanto, A. (2009). PENGARUH STABILISASI TANAH LEMPUNG DENGAN ASPAL EMULSI Klasifikasi tanah, 3(KoNTekS 3), 6-7.

Thesis, D. (2008). Geotechnical Aspects of Buildings on Expansive Soils in Kibaha, Tanzania. Buildings. Retrieved from http://www.diva-portal.org/smash/get/diva2:10579/FULLTEXT01.pdf Utami, S. (2018). Ketersediaan Air Bersih Untuk Kesehatan. Optimalisasi Peran Sains Dan Teknologi Untuk Mewujudkan Smart City, (June). Retrieved from https://www.researchgate.net/profile/sri_utami29/publication/326057942

Wardani, S. P. R., Muhrozi, M., Setiaji, A. R. A., \& Riwu, D. R. (2018). Stabilisasi Tanah Ekspansive dengan Menggunakan Tanah Putih untuk Tanah Dasar di Daerah Godong Kabupaten Grobogan Jawa Tengah. Media Komunikasi Teknik Sipil, 24(1), 1. https://doi.org/10.14710/mkts.v24i1.16275

Widhiarto, H., Andriawan, A. H., Matulessy, A., Teknik, F., \& Psikologi, F. (2015). STABILISASI TANAH LEMPUNG EKSPANSIF DENGAN MENGGUNAKAN CAMPURAN ABU-SEKAM DAN KAPUR, 01(02), 135-140.

Zaenuri, M. (2018). Penelitian Penggunaan Batu Gamping Sebagai Agregat Kasar Dan Filler Pada Aspal Campuran. UKaRsT, 2(1). https://doi.org/10.30737/ukarst.v2i1.357. 